\title{
指示棒の接触検知を用いたプレゼンテーション支援システム
}

\section{Presentation Support System}

\section{using Contact Detection of Pointing Stick}

\author{
児玉真悟 $1,2^{*}$, 大寺亮 1 \\ Shingo KODAMA ${ }^{1,2 *}$, Ryo OHTERA ${ }^{1}$
}

\section{1 神戸情報大学院大学情報技術研究科}

Graduate School of Information Technology, Kobe Institute Computing

$\bar{\top} 650-0001$ 兵庫県神戸市中央区加納町2-2-7

2 神戸電子専門学校

College of Computing, Kobe Institute of Computing

厂 650-0002 兵庫県神戸市中央区北野町1-1-8

E-mail: s.kodama@kobedenshi.ac.jp

*連絡先著者 Corresponding Author

教育現場でPC画面をプロジェクタで表示しながら行う講義が一般的となっている. しかし，PCから 離れ, スクリーンの近くで説明をしようとすると, その間はマウスによる複雑な操作を行うことができな い. そこで, 本研究では講義によく用いられる指示棒に着目し, Webカメラ映像から指示棒とスクリー ンの接触を検知することで, 直感的にPC操作を行う手法を提案する.

A lecture mirroring a lecturer's monitor on a projector screen is relatively common in the field of education. However, when a lecture talks about to the projector screen, the lecture can't do the computer operation involving complex mouse action. Therefore, in this study, we propose a contact detection method for a pointing stick to realize a direct computer operation on the projector screen.

キーワード: 指示棒, プレゼンテーション, 画像処理, 接触検知

Pointing Stick, Presentation, Image Processing, Contact Detection

\section{1 はじめに}

一般的なプレゼンテーションでは, 講演 者は講演卓に設置したコンピュータで操 作を行う。このため，スクリーンに投影さ れた資料の説明をしながらスライドの操
作を行おうとした場合, 講演者は通常Fig.1 に示すようにスライドの説明をした後, Fig.2にように操作の度に講演卓に戻らな ければならない.プレゼンテーションが中 断されている間, 聴講者は注目点を失って 手持ち無沙汰となり，集中力が切れてしま 
う。講演者もまた聴講者の反応の鈍化に釣 られてペースを乱される形となり，更に聴 講者が興味を失う悪循環に陥ってしまう。 結果として，時間の経過とともにプレゼン テーションの効果は低くなる.

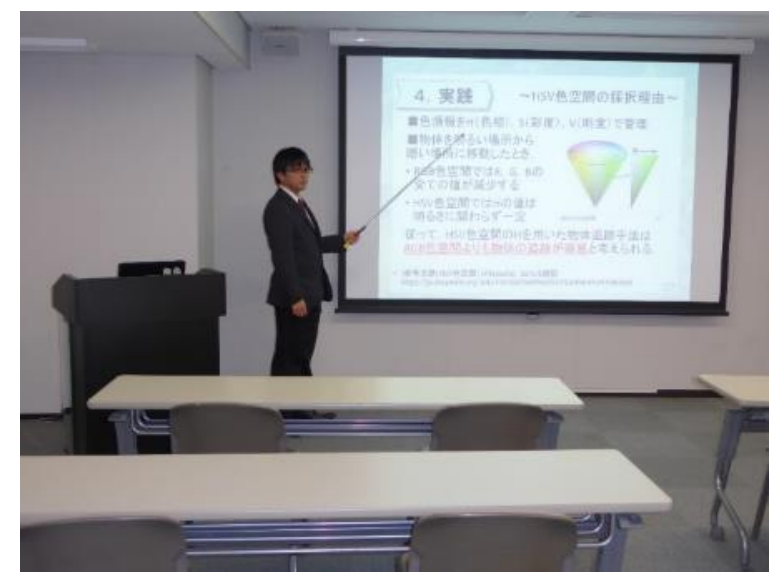

Fig.1 一般的な講義の様子

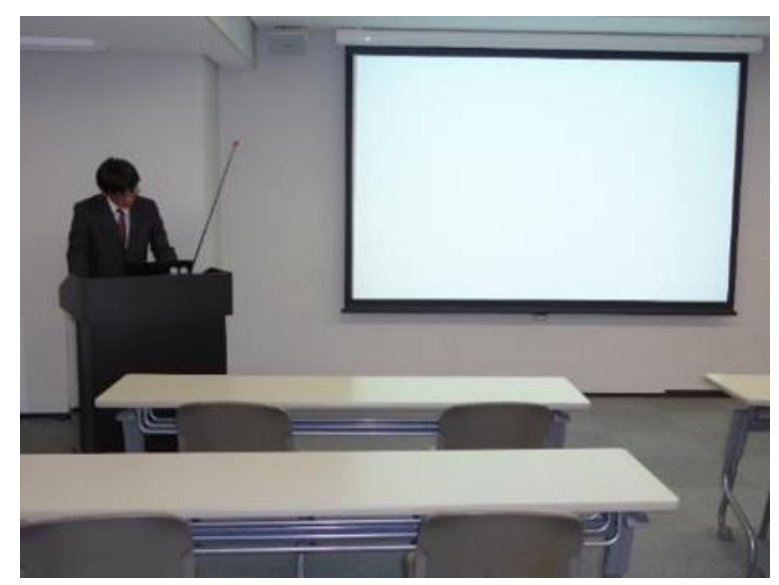

Fig.2 スライドの切り替え

一方でコンピュータ操作ボタン系デバイス を用いて遠隔操作を行う方法もあるが，操作 内容がボタン数に依存し, 複雑な操作を行う ことができない. そこで, 本研究では従来提案 されている, スクリーンに投影された画面を操 作パネルと見なして指示棒で操作する手法に 着目し, その拡張・改良によってコンピュータ 操作を行うシステムを提案する.

\section{2 既存研究亡問題点}

佐藤らは, CCDカメラ映像から指示棒の スクリーン接触を検知することで，コンピ ユータ操作を行うシステムを提案した[1]. 提案システムの構成をFig.3に示す. 提案シ ステムでは，スクリーンに投影された画面 の認識のため，事前にマウスによる4点指 定でキャリブレーションを行う。プレゼン テーション時にスクリーンに投影された 画面がカメラ映像内で最も明るくなる性 質を利用し，投影された画面の垂直成分毎 に明るさの下限值を取得することで前景 と画面の切り分けを行う。画面には予め GUIボタンを配置し，このボタンに指示棒 が触れることで，コンピュータに対するコ マンドが発行される。

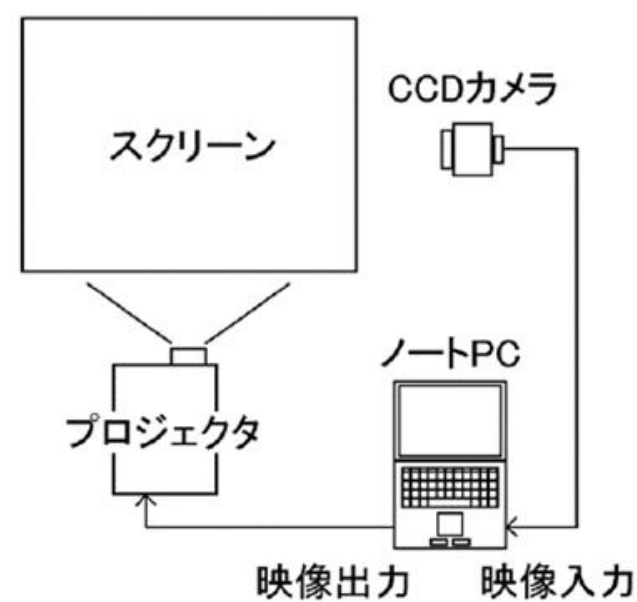

Fig.3 既存研究システム構成[1]

佐藤らは指示棒とスクリーンの接触を 検知するにあたり，指示棒によって作られ る影と指示棒自身に着目した。二值化画像 において，指示棒と影はスクリーンに接触 していない場合はFig.4(a)に示すような二 本の線分となり，スクリーンに接触してい る場合はFig.4(b)に示すようなくさび形を 形成する. 


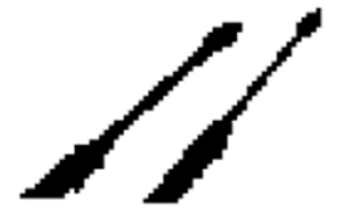

(a)非接触時

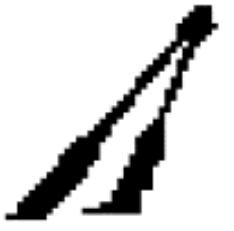

(b) 接触時
Fig.4 スクリーン非接触時と接触時にお ける指示棒と影[1]

接触検知のアルゴリズムとして, 二值化 画像における連結した黒画素群から, くさ び形を認識する手法が提案されている.

Fig.5に, 佐藤らによって提案された手法を 示す.この手法では抽出した連結成分を1 行ずつに分け, 行毎の黒画素群の数を計上 する. 対象の連結成分がくさび形である場

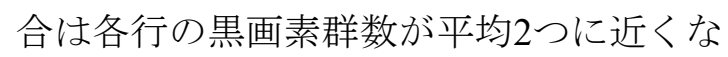
り, Fig.4(a)のような独立した線分である場 合は各行の黒画素群数は平均1つに近くな る. 従って, 平均個数が 2 に近い連結成分 をくさび形として認識することで, 指示棒 とスクリーンの接触検知を行っている.

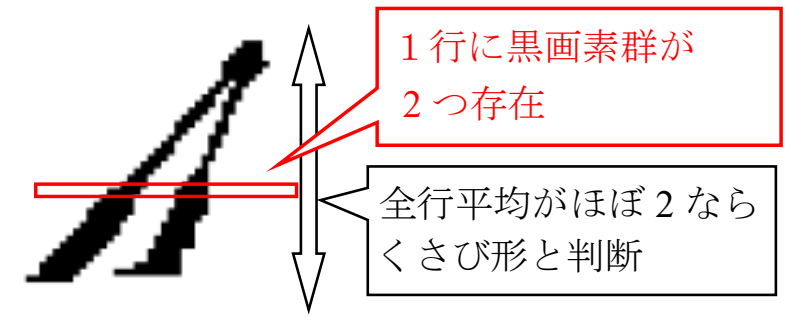

Fig.5 くさび形判定アルゴリズム

ただし，この手法ではくさび形ではない 形についてもくさび形として認識されて しまう可能性がある.例えばU字型やX字形 の図形が存在した場合にも，黒画素群の平 均個数が 2 に近くなるため, 指示棒の誤検 知が考えられる.また，このシステムでは 画面内にGUIボタンを配置する必要があり, 全画面のプレゼンテーション画面では使 用できない問題がある.

\section{3 提案手法}

既存研究の問題点を解決するため，改良 型のくさび形検出を利用したプレゼンテ ーション支援システムを提案する。システ ムの全体構成をFig.6に示す. 提案システム では指示棒を持った話者と資料が投影さ れたスクリーンをWebカメラで撮影する. キャリブレーションのため, システム使用 開始時，使用者は予めスクリーンの四隅を 動画像内で指定しておく. 動画像内でスク リーンと指示棒の接触が検知できた場合 に座標を取得し，話者が示している箇所を 特定し，操作に反映する.

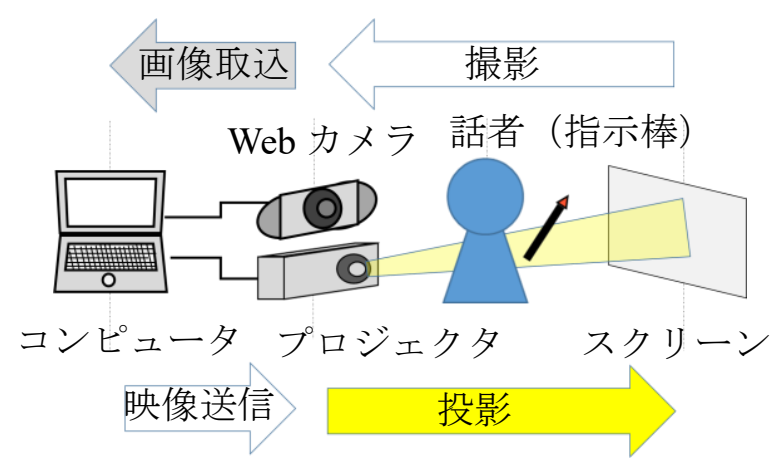

Fig.6 支援システムの構成

本手法ではくさび形検出の精度を向上 させるため, Fig.7に示すフローにより， Webカメラから取得した動画像フレームに 対して種々の画像処理を行う.

システムはWebカメラから得たRGB画 像をグレースケール画像に変換し, 更に適 応的閾值処理を施した二值化画像に変換 する.ここまでの処理を行った画像の例を Fig.8に示す. 更に, 話者が指示棒でスライ ド内を指示する場合にはスクリーンの境 界, 指示棒, 話者が繋がって画面内で最大 の連結黒点となる性質を利用し, 規定值以 下の連結黒点を除外することでシステム の高速性とノイズ除去を図る。また，スク 


\begin{tabular}{l}
\hline Web カメラから RGB 色空間画像を取込 \\
$\downarrow$ \\
\hline$\downarrow$ \\
\hline グレースケール画像に変換 \\
\hline$\downarrow$ \\
\hline 適応的閾值処理を施した二值化画像に変換 \\
\hline$\downarrow$ \\
\hline 規定值以上の連結黒点を抽出 \\
\hline$\downarrow$ \\
\hline 長水平成分, 長垂直成分を検出して認識 \\
\hline \\
\hline 画像に対してくさび形検出アルゴリズムを \\
適用し, 検出されたくさび形をスコア化 \\
\hline
\end{tabular}

Fig.7 画像処理フロー

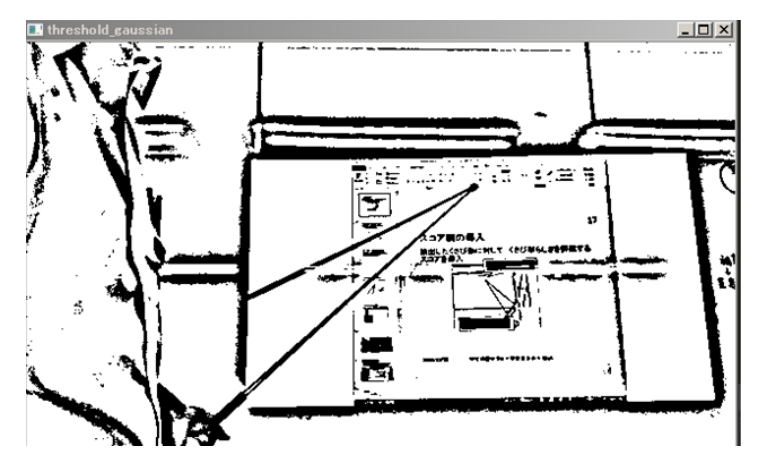

Fig. 8 取得画像の二值化

リーンやウィンドウ，投影資料内容等によ って生じる直線をくさび形の候補から除 外するため, 長水平成分, 長垂直成分を検 出し，くさび形検出の際にノイズとして考 慮し, 後のスコア付けの際に重みを軽くす る. 最後に, 画像の中からくさび形を検出 し，スコア化を行う。くさび形の検出では まず，画像下部より一行ずつ走査し，同じ 行内に存在する二つの黒点群を探索する. 二つの黒点群が見つかり, かつ画像上部で 二本の線分として交差している場合, 線分 の長さや直線具合，ノイズの有無等によっ てスコア付けを行う. スコア化の結果, 基 準值以上のくさび形を指示棒とその影に よって形成されたくさび形であるとして 検出する. 指示棒と影によるくさび形を検
出した例をFig.9に示す.

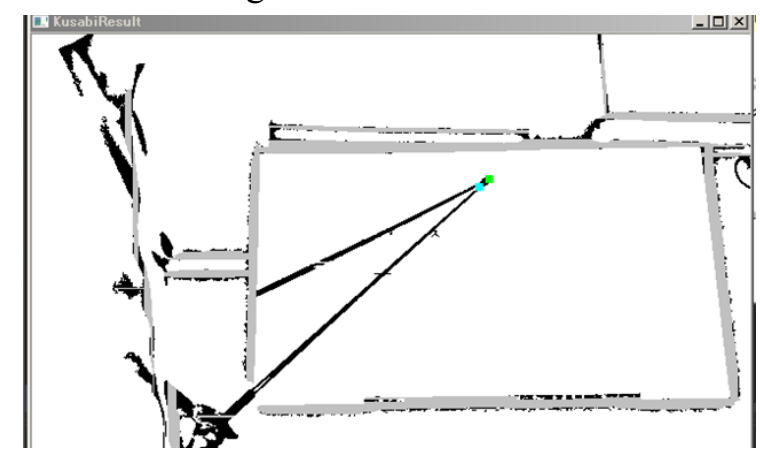

Fig.9 指示棒と影によるくさび形の識別

実装したアルゴリズムの評価をおこな ったところ, 背景が黒に近い低階調画面で は指示棒の影ができずにくさび形が形成 されない，画面端を指した場合には影の長 さが十分に確保できずにくさび形と認識 され辛い，スライド上の細い斜線を指示棒 と誤認する等の問題が生じることが確認 された. Fig.10に，指示棒とスライド内の 斜線によって誤検知された例を示す.

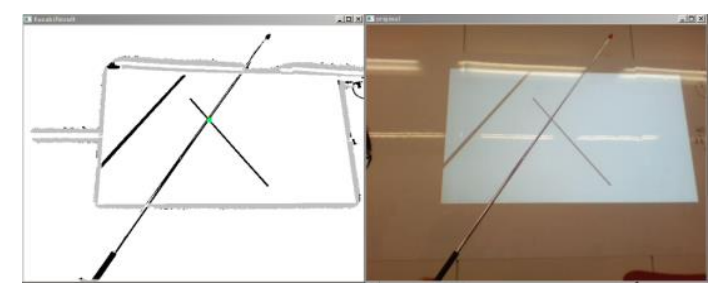

Fig.10 スライド上の斜線による誤検知

以上のような問題が生じているものの, 誤検出されるシーンは限定的であるため, システムとしての運用は可能であると考 えられる。

\section{4 効果検証}

3章で提案したアルゴリズムを応用し， 指示棒をマウスの代わりとして使用でき るようにした上で，複数の被験者に対して 演習込みの講義を行う形で実験を実施し た．実験に際しては本システムを用いた講 
義と従来通りの講義を個別に実施し, 被験 者の行動にみられる変化を確認すること とした. Fig.11に実験の様子を示す.また， 被験者の座席に(1)〜 (7)の番号を設け, シス テムの有無による違いを座席毎に比較で きるようにした。

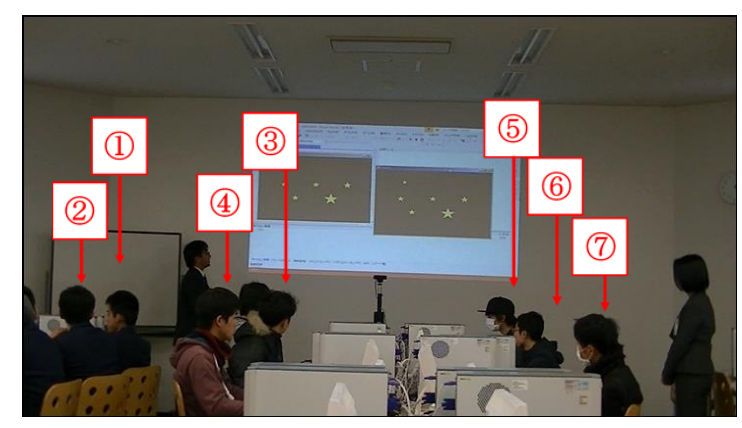

Fig.11 評価実験の様子ならびに席番号

実験に際しては, 以下の内容を条件とし て定めた.

・講義は他のプログラミング言語よりもマ ウス操作が多いVisualBasicを題材とした

・3回の講義（内2回をシステム有, 1回を システム無しで行う）の内容はシステム
の有無に関わらず同一の内容とし, 毎回 異なる被験者に対して行う

・被験者はプログラミングについて経験が 無い，または浅い者とした。今回の実験 においてはコンピュータプログラミング に興味を持つ高校 1 年生〜 3 年生を主な夕 ーゲットとした

・被験者が話者またはプロジェクタによっ て投影された画面を向いている状態を前 向き状態とし，前向き状態でない状態を その他状態とした．講義全体における前 向き状態の割合を前向率とした上で，シ ステム有無による前向率の違いを調べた

・講義の様子を後方からビデオによって撮 影し, 後で前向率の集計を行うこととし た。この際, 補助員や他の被験者が被つ ていて目視方向が確認できない場合は, 該当の時間を集計対象外とした

Table 1にシステム有1回目の被験者個別 の結果を, Table 2にシステム有2回目の被 験者個別の結果を, Table 3にシステム無の

Table 1 システム有 1 回目の被験者別前向率集計結果

\begin{tabular}{|c|r|r|r|r|r|r|r|}
\hline & \multicolumn{1}{c|}{ (1) } & \multicolumn{1}{c|}{ (2) } & \multicolumn{1}{c|}{ (3 } & \multicolumn{1}{c|}{ (4) } & (5) & \multicolumn{1}{c|}{6} & (6) \\
\hline 前向き状態(秒) & 703 & 709 & 914 & 1084 & 1141 & 799 & 1043 \\
\hline その他状態(秒) & 1113 & 1064 & 1100 & 931 & 855 & 1214 & 976 \\
\hline 除外対象(秒) & 204 & 247 & 6 & 5 & 24 & 7 & 1 \\
\hline 前向率 & $38.7 \%$ & $40.0 \%$ & $45.4 \%$ & $53.8 \%$ & $57.2 \%$ & $39.7 \%$ & $51.7 \%$ \\
\hline
\end{tabular}

Table 2 システム有 2 回目の被験者別前向率集計結果

\begin{tabular}{|c|r|r|r|r|r|r|r|}
\hline & \multicolumn{1}{c|}{ (1) $)$} & \multicolumn{1}{c|}{ (2) } & \multicolumn{1}{c|}{ (3) } & \multicolumn{1}{c|}{ (4) } & \multicolumn{1}{c|}{ (5 } & \multicolumn{1}{c|}{6} & \multicolumn{1}{c|}{7} \\
\hline 前向き状態(秒) & 814 & 846 & 1126 & 1047 & 1073 & 1281 & 869 \\
\hline その他状態(秒) & 535 & 686 & 1108 & 1179 & 1174 & 965 & 1236 \\
\hline 除外対象(秒) & 898 & 715 & 13 & 21 & 0 & 1 & 142 \\
\hline 前向率 & $60.3 \%$ & $55.2 \%$ & $50.4 \%$ & $47.0 \%$ & $47.8 \%$ & $57.0 \%$ & $41.3 \%$ \\
\hline
\end{tabular}

Table 3 システム無の被験者別前向率集計結果

\begin{tabular}{|c|c|c|r|r|r|r|r|}
\hline & (1) & (2) & \multicolumn{1}{c|}{$(3)$} & (4) & 5 & 6 & \multicolumn{1}{c|}{7} \\
\hline 前向き状態(秒) & - & - & 619 & 570 & 580 & 855 & 994 \\
\hline その他状態(秒) & - & - & 1693 & 1872 & 1863 & 1579 & 1449 \\
\hline 除外対象(秒) & - & - & 131 & 1 & 0 & 9 & 0 \\
\hline 前向率 & - & - & $26.8 \%$ & $23.3 \%$ & $23.7 \%$ & $35.1 \%$ & $40.7 \%$ \\
\hline
\end{tabular}


被験者個別の結果を示す。また，それぞれ の実験結果のまとめをTable 4に示す. Table 2の(1)，(2)の被験者については講義の補助 指導員の影に隠れてしまい，2割以上の時 間が無効となったためTable 4には反映し ていない. また, Table 3の(1), (2)について は空席であった。

Table 4 システム有無の講義時間と前向率

\begin{tabular}{|c|c|c|c|}
\cline { 2 - 4 } \multicolumn{1}{c|}{} & $\begin{array}{c}\text { システム有 } \\
1 \text { 回目 }\end{array}$ & $\begin{array}{c}\text { システム有 } \\
2 \text { 回目 }\end{array}$ & $\begin{array}{c}\text { システ } \\
\text { ム無 }\end{array}$ \\
\hline 総時間 & $\begin{array}{c}34 \text { 分 } \\
34 \text { 秒 }\end{array}$ & $\begin{array}{c}37 \text { 分 } \\
26 \text { 秒 }\end{array}$ & $\begin{array}{c}40 \text { 分 } \\
42 \text { 秒 }\end{array}$ \\
\hline $\begin{array}{c}\text { 集計 } \\
\text { 対象 }\end{array}$ & 7 人 & 5 人 & 5 人 \\
\hline $\begin{array}{c}\text { 前向率 } \\
\text { 平均 }\end{array}$ & $46.8 \%$ & $48.8 \%$ & $30.0 \%$ \\
\hline $\begin{array}{c}\text { 前向率 } \\
\text { 最大 }\end{array}$ & $57.2 \%$ & $57.0 \%$ & $40.7 \%$ \\
\hline $\begin{array}{c}\text { 前向率 } \\
\text { 最小 }\end{array}$ & $38.7 \%$ & $41.3 \%$ & $23.3 \%$ \\
\hline
\end{tabular}

Table 4の結果から，システムを用いない 講義における前向率が平均 $30.0 \%$ だったの に対し, システムを用いた講義では平均 40\%後半を示しており, およそ20\%の前向 率改善が行われたと判断できる.また, 前 向率改善の影響で, システム無の場合には 40分を要していた講義時間が，システム有 の場合には3分〜7分ほど短縮された。この 理由として, 被験者が前方のプロジェクタ 画面に長く注目することで操作方法が明 確となり，演習時間が短くなったことが挙 げられる.また, 席別の結果を比較すると, 演習用PCとプロジェクタ画面, 話者の見比 べに大きく首を振る必要がある(3), (4), (5) の席ではシステムの有無で2倍以上の前向 率の変化が見られた。この結果から, シス テム無では何度も画面を見比べるにつれ
て被験者が疲れ，次第にプロジェクタ画面 を見なくなっているものと推測される。こ の結果から，当初の問題であった聴講者の 集中力低下問題に対し，本システムが有効 に働いたことが示唆される.一方で, 比較 的演習用PCとプロジェクタ画面, 話者の見 比べに大きく首を振る必要が無い(6), (7)の 座席については, システムの有無が有意と は言えない結果となった。元より見比べの 負担が少ない座席に対しては効果が薄い と考えられる。

\section{5 おわりに}

本研究では指示棒のスクリーン接触時 に現れるくさび形の検出アルゴリズムを 考案し, 指示棒を操作デバイスとして扱え るシステムを提案した。誤検知や認識率低 下の課題が残るものの, 実使用において被 験者の前向率を向上させ, 集中力を高める ことに成功した上で講義の効率化を図る ことができた。今後は低階調な画面での指 示棒検出方法の確立や, スライド内の斜線 等による誤検知の減少を図ることで，シス テムの更なる利便性向上を模索する.

\section{謝辞}

本研究の効果確認に際し, オープンキャ ンパス体験授業を実験フィールドとする にあたって多大なご協力を頂いた, 神戸電 子専門学校企画部広報IT担当の小川洋氏に 深く感謝申し上げます。

\section{参考文献}

[1] 佐藤 周平, 柴山悦哉, 高橋伸, “指示 棒の認識を用いたプレゼンテーションシ ステムの構築, ”コンピュータ ソフトウェ ア, Vol. 17, No. 3, pp.269-272, 1999. 